\title{
ACTIVITY OF ALKALINE PHOSPHATASE IN THE MAJOR SALIVARY GLANDS OF MICE AT VARIOUS AGES OF POSTNATAL LIFE, AND DURING PREGNANCY AND LACTATION
}

\author{
Blanka Pospísilová, Dáša Slížová, Olga Procházková, Otakar Krs, Petr Bílek \\ Department of Anatomy, Charles University, Faculty of Medicine, Hradec Králové; \\ (Head: MUDr. B. Pospíšilová, CSc.)
}

\begin{abstract}
Summary: Activity of alkaline phosphatase in the major salivary glands of male and female mice at various ages of postnatal life, and in females during pregnancy and lactation was studied histochemically. Enzyme activity was not detected on the day of birth, but was found in the terminal tubules of all major salivary glands during the first postnatal week. Alkaline phosphatase activity was increasing gradually with age and a definitive enzymatic pattern was observed by the age of 6 weeks. No difference in enzyme activity was found among the major salivary glands of young adult and old animals. The parenchyma of fully differentiated submandibular glands showed clear sexually dimorphic patterns of alkaline phosphatase activity. During pregnancy, a significant increase of alkaline phosphatase activity was detected in submandibular gland. From gestation day 15 to the end of pregnancy, enzymic pattern of granular convoluted tubules of pregnant females was the same as in the adult males. Histochemical masculinization of the submandibular gland during pregnancy suggests that besides androgens also progesterone exerts masculinization of the murine submandibular salivary gland.
\end{abstract}

Key words: Major salivary glands; Submandibular gland; Sublingual gland; Parotid gland; Histochemistry; Alkaline phosphatase; Sexual dimorphism; Mouse

\section{Introduction}

The major salivary glands (MSGs) of mouse are the submandibular, sublingual and parotid glands. The submandibular gland (SMG) is situated on both sides of the midline on the floor of the oral cavity; the sublingual gland (SLG) closely adjoins at the anterolateral surface of the submandibular gland; the parotid gland (PG) lies dorsolaterally behind the ear (Fig.1). In mice, major salivary glands are not fully developed at birth and continue to differentiate during several postnatal weeks. The parenchyma of the salivary glands in newborn mice is composed of rudimentary secretory units known as terminal tubules (TTs) (30).The fully differentiated parenchyma of the rodent major salivary glands comprises morphological units composed of acini (Ac), intercalated ducts (IDs), striated ducts (SDs), and excretory ducts (14,25). In addition, the SMG of mice contains granular convoluted tubules (GCTs) representing secretory structures between the intercalated and striated ducts - they differentiate from the upper parts of the SDs postnatally $(25,30)$ (Fig. 2). The SMG of mice is an androgen-dependent organ (8) showing sexual dimorphism in adult animals $(1,7,14,17,23,28)$. This sex dimorphism is morphologically characterized by three features: 1) larger and more frequent GCTs in males, 2) fe- wer SDs in males, 3) granular IDs in females. The cells of mouse GCTs contain a lot of biologically active polypeptides, much more in males than in females (2).

Although MSGs of mice have been extensively studied morphologically $(1,7,9,10,14,17,25,26,28,30,31)$, histochemical and immunohistochemical studies of mouse salivary glands are less frequently found in the literature $(1,14,15,26,29)$.

The present study was aimed to determine the time of appearence of alkaline phosphatase (AP) activity in murine MSGs, as well as enzyme activity changes in the parenchyma and the capillary endothelial bed of murine MSGs during various periods of postnatal life, and during pregnancy and lactation. However, to our knowledge no reports are available on the distribution of AP activity in murine MSGs during postnatal glandular parenchyma differentiation, or during pregnancy and lactation.

AP (non-specific alkaline phosphatase, orthophosphoric-monoester phosphohydrolase) (EC 3.1.3.1), one of the most important enzymes in histochemistry, hydrolyzes various phosphate esters at alkaline $\mathrm{pH}$. AP has been investigated histochemically, imunohistochemically or biochemically in many tissues and organs of various mammals: e.g., in the rat bone (24) and intestine (34), mouse uterus and placenta (16), rat uterus (6), and rat, cat, dog and man 
salivary glands $(3,12,13,18)$. Only two histochemical studies have demonstrated the distribution of AP in SMG of adult mice of both sexes $(1,14)$.

AP is also known as an excellent marker of capillary endothelial cells (CECs) $(19,27)$, usually in the arterial part of the capillary bed (19). Membrane localization of this phosphatase strongly suggests its function in membrane active transport, but the mechanism is not known as yet (5). Analysis of AP in mice with defective vitamin B-6 metabolism suggests involvement of AP in vitamin B-6 metabolism in the central nervous system (32), however, its biological and physiological roles in other tissues remain unknown.

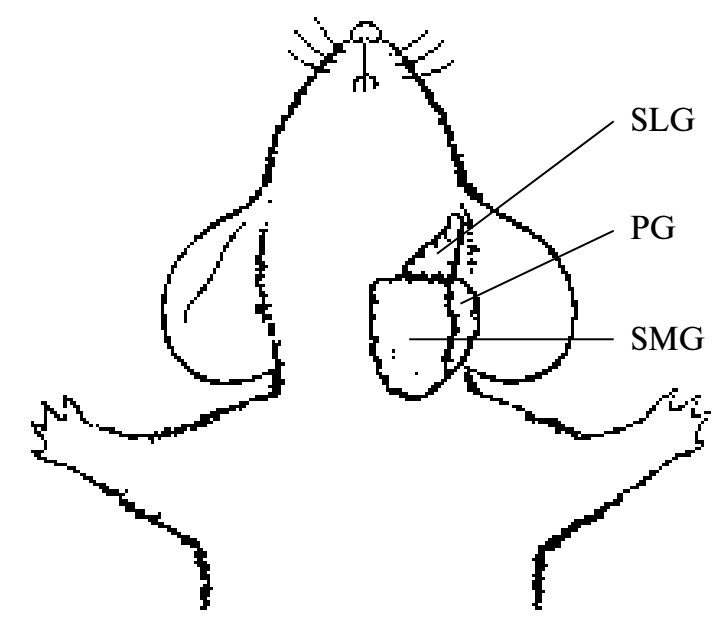

Fig. 1: Position of murine major salivary glands.

SLG - sublingual gland, PG - parotid gland, SMG - submandibular gland.

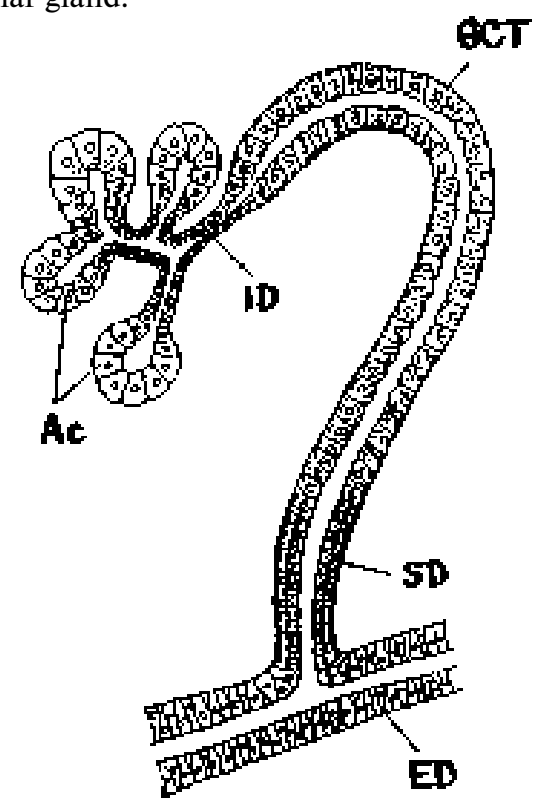

Fig. 2: Schematic presentation of a major salivary gland. Ac - acini, ID - intercalated duct, GCT- granular convoluted tubule (in submandibular gland only), SD - striated duct, ED - excretory duct.

\section{Materials and methods}

\section{Experimental animals}

Sixty ICR mice, 20 males and 40 females, were used in this study. Experimental mice were assigned to six groups of 10 animals each ( 5 males and 5 females in groups N, P, Y, O; 10 females in groups G, L), and classified as follows:

group N: early postnatal period (newborn males and females aged 0-7days; the day of birth was counted as day zero)

group P: prepubescent and pubescent period (prepubescent males and females aged 1-3 weeks; pubescent males and females aged 4-6 weeks)

group Y: young adult period (males and females aged 7-20 weeks)

group O: old adult period (males and females aged 24-26 months)

group G: pregnancy (5-day-, 10-day-, 15-day-, 21-day-pregnant females; 21 st day of gestation $=$ birth of offspring)

group L: lactation (5-day-, 10-day-, 15-day-lactating females; 21 st day of lactation $=$ day of weaning)

\section{Histochemistry}

SMG, SLG and PG were removed bilaterally in each animal and rapidly frozen. For light microscopy, cryostat sections $(20 \mu \mathrm{m})$ were used. Histochemical detection of AP was carried out by the simultaneous coupling method of Burstone, 1962 (4); the succedaneous enzymatic method in the combination AP/ AChE (acetylcholinesterase) was sometime used. Parallel detection of AP and AChE (direct-colouring thiocholine method of Karnovsky and Roots, 1964) (21) in the same section was used for better topical orientation in histochemical sections and for complex mapping of the capillary bed.

\section{Results}

Histochemical patterns of AP activity in the SMG, SLG and $\mathrm{PG}$ of mice of both sexes at various ages of postnatal life, and in the MSGs of female mice during pregnancy and lactation are shown in Table 1.

\section{AP activity in MSGs during the early postnatal period (group $N$ ) (Fig. 3, 4)}

On day zero, all components of the gland parenchyma and likewise the CECs were entirely unreactive for AP. On day 2, apical cell membranes of TTs in the SMG and SLG began to react weakly positive. On day 4, first signs of AP activity were seen in the TTs of PG and in IDs of SMG. AP activity was slowly increasing during the next days of the 1st week. Slight AP activity in the CECs of the arterial part of the capillary bed of all MSGs was detected between day 1 and day 7. No sex difference in enzyme activity pattern was seen in the glands during the early postnatal period. 
Tab. 1: Histochemical patterns of AP activity in the major salivary glands in several groups

\begin{tabular}{|c|c|c|c|c|c|c|}
\hline & $\begin{array}{c}\text { GROUP Newborn } \\
\text { animals }\end{array}$ & $\begin{array}{c}\text { GROUP P } \\
\text { prepubescent and } \\
\text { pubescent animals }\end{array}$ & $\begin{array}{c}\text { GROUP Y } \\
\begin{array}{c}\text { young adult } \\
\text { animals }\end{array}\end{array}$ & $\begin{array}{c}\text { GROUP O } \\
\begin{array}{c}\text { old adult } \\
\text { animals }\end{array}\end{array}$ & $\begin{array}{c}\text { GROUP G } \\
\begin{array}{c}\text { pregnant } \\
\text { females }\end{array}\end{array}$ & $\begin{array}{c}\text { GROUP L } \\
\begin{array}{c}\text { lactating } \\
\text { females }\end{array}\end{array}$ \\
\hline SMG & $\begin{array}{l}\left.\text { TT ( } 2^{\text {nd }} \text { day }\right) \text { ar } \\
\left.\text { ID ( } 4^{\text {th }} \text { day }\right) \text { ar } \\
\pm \rightarrow++ \\
\text { CEC + }\end{array}$ & 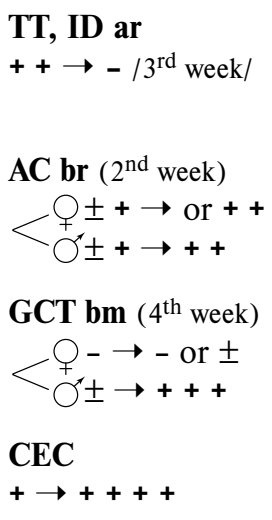 & $\begin{array}{l}\text { AC br } \\
<++ \text { or }++ \\
O^{4}+++ \\
\text { GCT bm } \\
<+9 \text { or } \pm \\
O+++ \\
\text { CEC } \\
++++\end{array}$ & $\begin{array}{l}\text { AC br } \\
+ \text { or }++ \\
+++ \\
\text { GCT bm } \\
<+- \text { or } \pm \\
\text { + +++ } \\
\text { CEC } \\
++++\end{array}$ & $\begin{array}{l}\text { AC br } \\
++ \\
\text { GCT bm } \\
- \text { or } \pm \rightarrow+++ \\
\text { CEC } \\
++++\end{array}$ & $\begin{array}{l}\text { AC br } \\
++\rightarrow+ \\
\text { GCT bm } \\
+++\rightarrow \pm \text { or }- \\
\text { CEC } \\
++++\end{array}$ \\
\hline SLG & $\begin{array}{l}\left.\text { TT (2 } 2^{\text {nd }} \text { day }\right) \text { ar } \\
\pm \rightarrow++ \\
\text { CEC }+\end{array}$ & $\begin{array}{l}\text { TT ar } \\
++\rightarrow-/ 3^{\text {rd }} \text { week } / \\
\left.\text { AC br ( } 2^{\text {nd }} \text { week }\right) \\
\pm \rightarrow+ \\
\text { CEC } \\
+\rightarrow++++\end{array}$ & $\begin{array}{l}\text { AC br } \\
+ \\
\text { CEC } \\
++++\end{array}$ & $\begin{array}{l}\text { AC br } \\
+ \\
\text { CEC } \\
++++\end{array}$ & $\begin{array}{l}\text { AC br } \\
+ \\
\text { CEC } \\
++++\end{array}$ & $\begin{array}{l}\text { AC br } \\
+ \\
\text { CEC } \\
++++\end{array}$ \\
\hline $\mathbf{P G}$ & $\begin{array}{l}\text { TT (4th day) ar } \\
\pm \rightarrow+ \\
\text { CEC + }\end{array}$ & $\begin{array}{l}\text { TT ar } \\
+\rightarrow-/ 3 \text { rd week } / \\
\left.\text { AC br (2 } 2^{\text {nd }} \text { week }\right) \\
\pm \rightarrow+ \\
\text { CEC } \\
+\rightarrow++++\end{array}$ & $\begin{array}{l}\text { AC br } \\
+ \\
\text { CEC } \\
++++\end{array}$ & $\begin{array}{l}\text { AC br } \\
+ \\
\text { CEC } \\
++++\end{array}$ & $\begin{array}{l}\text { AC br } \\
+ \\
\text { CEC } \\
++++\end{array}$ & $\begin{array}{l}\text { AC br } \\
+ \\
\text { CEC } \\
++++\end{array}$ \\
\hline
\end{tabular}

SMG: submandibular gland

SLG: sublingual gland

PG: parotid gland

ar: apical cell region

br: basal cell region

bm: basal cell membranes (day, weak): date of the $1^{\text {st }}$ signs of activity /weak/: date of disappearance of activity

$\rightarrow$ : increase /decrease of activity

$\because$ negative $\quad++$ : moderate

+ -:trace $\quad+++$ : intense

+ : slight $\quad++++$ : extremely intense
TT: terminal tubules

ID: intercalated ducts

Ac: acini

GCT: granular convoluted tubules CEC: capillary endothelial cells
AP activity in MSGs during the prepubescent and pubescent period (group P) (Fig. 5)

AP activity in TTs and IDs was gradually decreasing to disappear around week 3. However, enzyme activity in the region of developing Ac appeared during the 2nd postnatal week. In all MSGs reaction product outlined basal parts of acini. AP activity in Ac was gradually increasing with age (more rapidly in SMG). No sexual differences in AP activity in SMG of prepubescent (2-3-week-old) animals were observed, but histochemical sexual differences in SMG of pubescent mice (from the 4th week of age on) were seen. During the 4th week, the male SMG Ac displayed rapidly increasing activity, while AP activity in female Ac increased very slowly. The first signs of AP activity in male SMG GCTs were detected during the course of the 4th postnatal week. However, female GCTs stayed enzyme negative at the same time. Between the 4th and 6th postnatal weeks enzyme activity in male GCTs was gradually increasing. During this period, female GCTs displayed none or only sporadic, very slight AP positivity. No enzymic sex differences were seen in SLG and PG. A definitive enzymic pattern was observed in the glands of animals aged six weeks. AP activity in the CECs during the first six postnatal weeks increased also. When histochemically examined by the succedaneous 


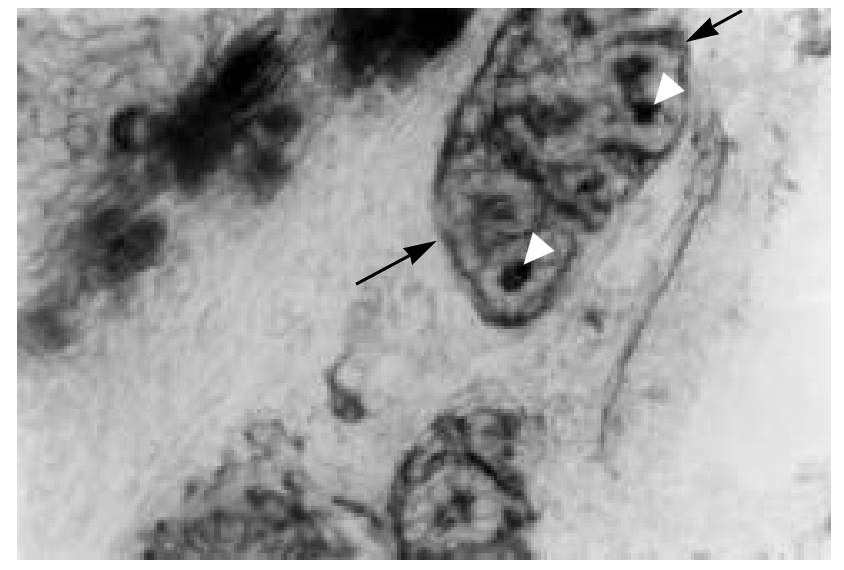

Fig. 3: Parallel detection of $\mathrm{AP} / \mathrm{AChE}$ in parotid gland of newborn mouse (6-day-old male). The micrograph shows the moderate AP activity in apical parts of terminal tubules (small arrows). Basal parts of terminal tubules stains for AChE (large arrows). 230x.

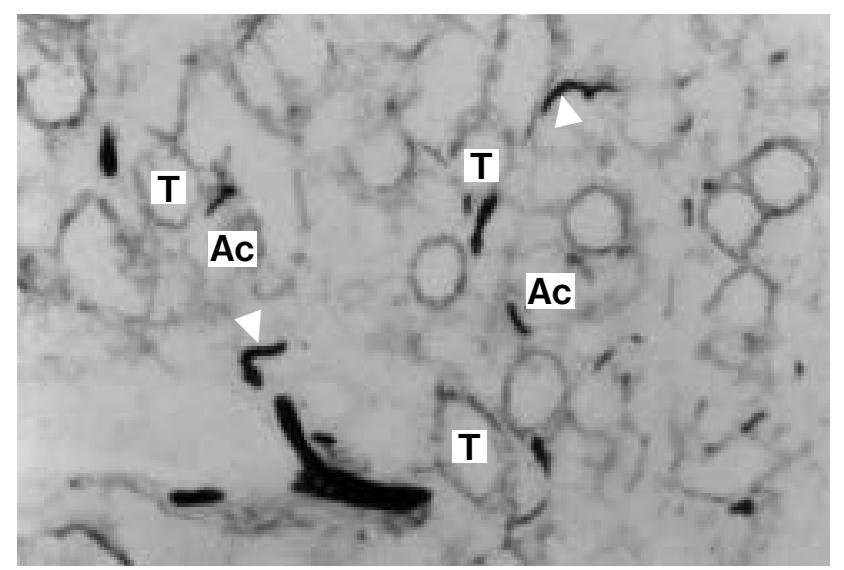

Fig.5: In the submandibular gland of thirty-five-day-old pubescent male, basal cell membranes of developing granular convoluted tubules (T) and basal parts of acini (Ac) show moderate staining for AP. Strong AP reaction is present in arterial parts of numerous capillaries (arrows). 150x.

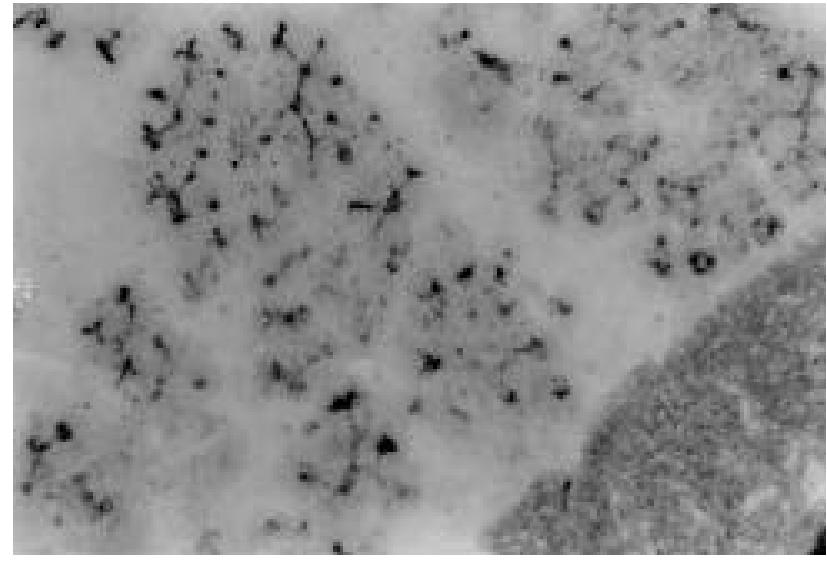

Fig. 4: AP activity in apical parts of terminal tubules and intercalated ducts of submandibular gland of 6-day-old female mouse. $150 x$.

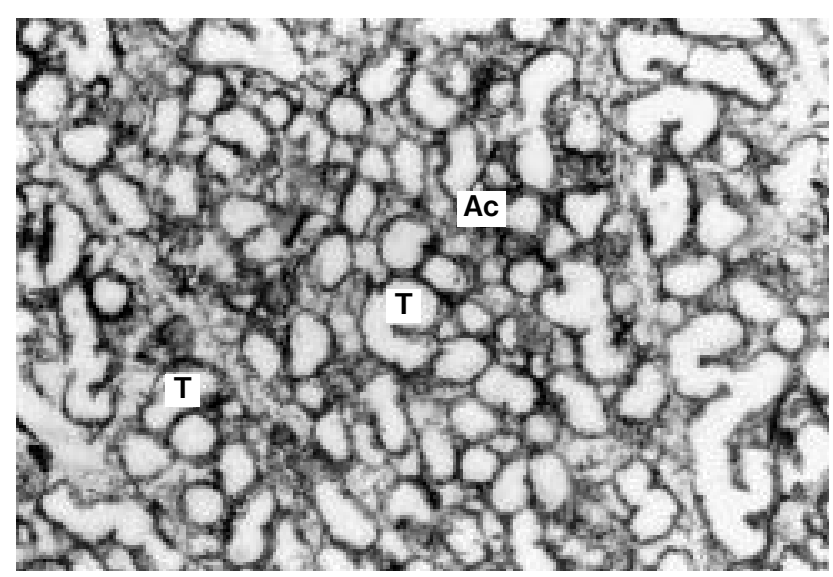

Fig.6: Strong AP activity in basal parts of granular convoluted tubules (T) and acini (Ac) of submandibular gland of young adult male ( 9 weeks of age). 100x. 


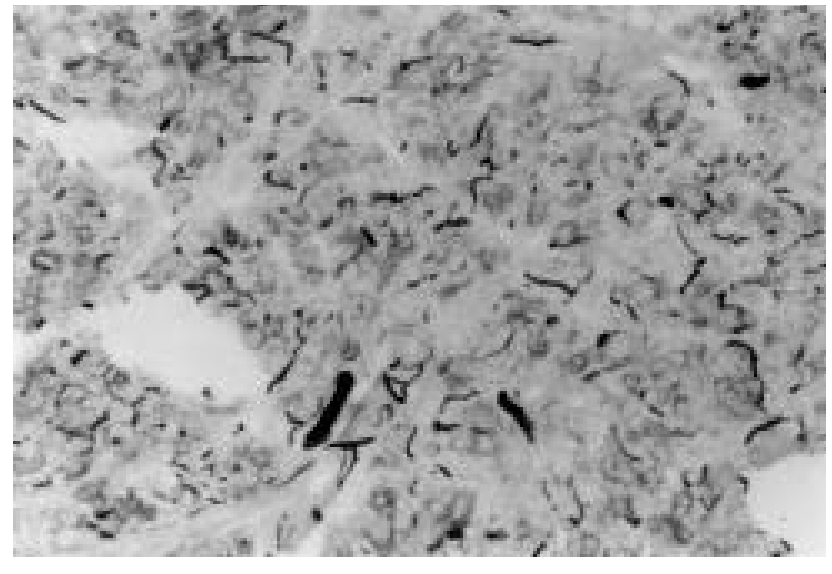

Fig. 7: In submandibular gland of young adult 9-week-old female, basal parts of acini show only weak or moderate AP activity. 100x

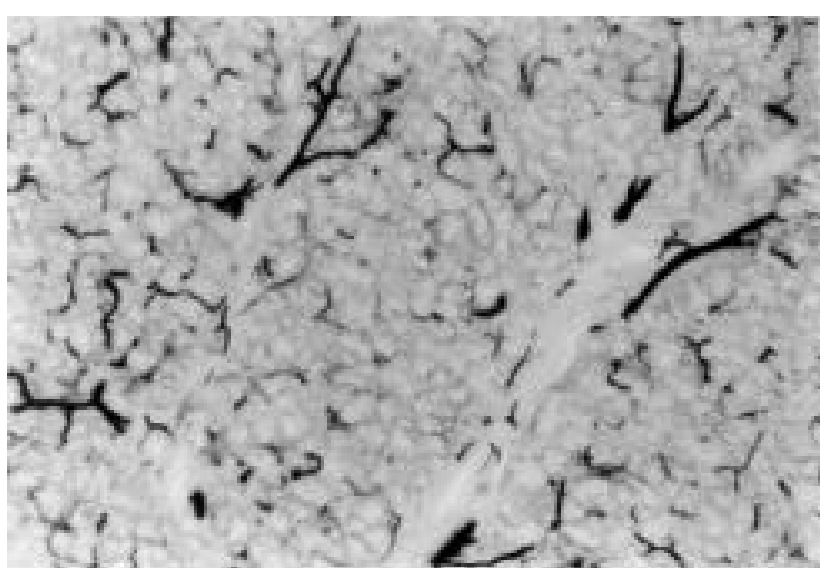

Fig.8: The AP activity in the sublingual gland of young adult 10 -weak-old male. The reaction in basal parts of acini is weak, whereas in arterial parts of numerous capillaries there is an intense pattern of enzymic activity. 100x.

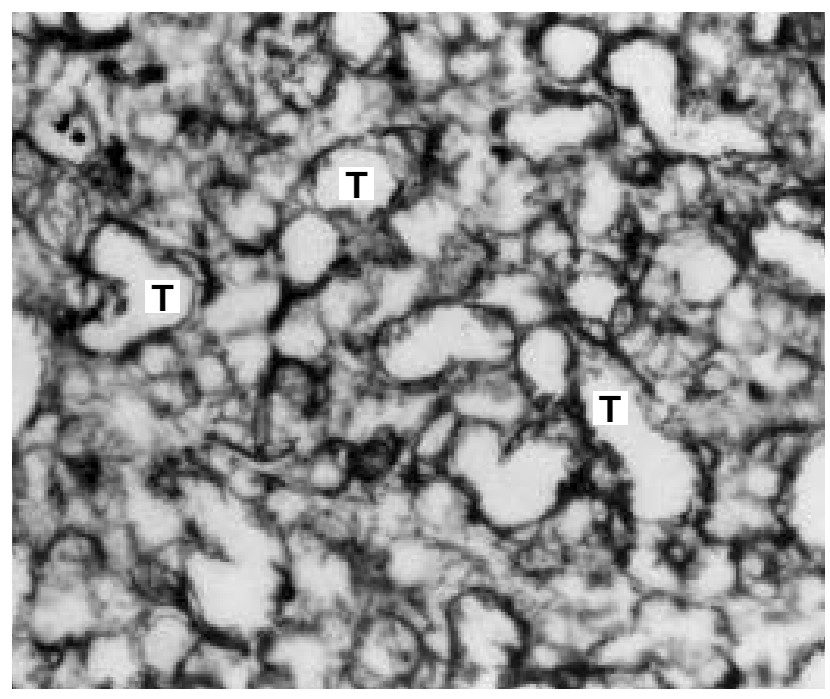

Fig. 9: The submandibular gland of 21-day-pregnant female shows clear pattern of histochemical masculinization. Strong AP reaction is seen in numerous granular convoluted tubules (T). The enzymic pattern is the same as in adult male SMG (see Fig. 6). 150x.

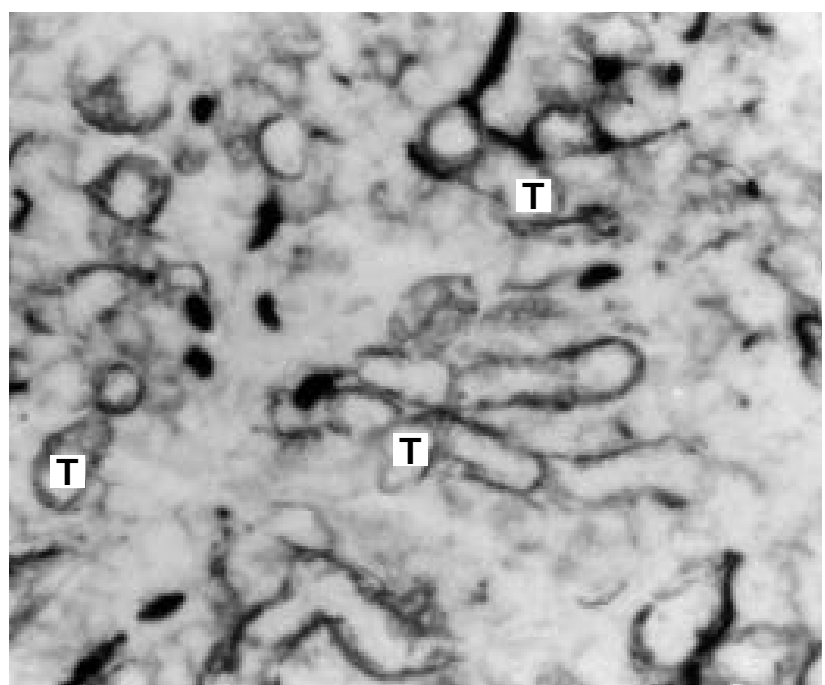

Fig. 10: During lactation, AP activity in the submandibular gland gradually decreases. However at the 10th day of lactation, the moderate AP activity in basal cell membranes of granular convoluted tubules $(\mathrm{T})$ is still present. 150x. 
enzymatic methods for AP and AChE, the arterial segment of capillary bed revealed the AP activity in contrast with the AChE-stained venous segment of the capillary bed. The middle part of the capillary bed between those segments displayed activity of both enzymes.

\section{AP activity in MSGs during young and old adult periods (groups $Y, O$ ) (Fig. 6, 7, 8)}

No difference was found in AP activity of the parenchyma of MSGs between young adult (group Y) and old animals (group $\mathrm{O}$ ), and no enzymic sex differences were detected between AP activity of the SLG and PG. The parenchyma of the SMG demonstrated a more intense reaction than the parenchyma of the SLG or PG. AP activity of fully matured SMG showed clear signs of histochemical sexual dimorphism. Strong enzymic reaction was found in the basal cell membranes of male GCTs, but none (or only sporadic trace reaction) in the female GCTs. Moreover, the GCTs were more frequent and larger in the male than in the female animals. AP activity in the basal cell region of mature SMG Ac was also more intense in males than in the females. Arterial parts of the capillary bed displayed strong AP activity without gland and sex differences.

\section{AP activity in MSGs during pregnancy (group G) (Fig. 9)}

In the SLG and PG of pregnant females, the enzymic pattern was the same as in adult males or adult non-pregnant females (groups Y, O). However, dramatic histochemical changes were detected in SMG during the course of pregnancy. On the 5th day of gestation, slight AP activity was seen in the basal cell membranes of all GCTs. From gestation day 15 throughout the end of pregnancy till the 21 pregnancy day (birth of offspring), enzyme activity of GCTs reached a maximum. At this time the enzymic pattern of pregnant GCTs was the same as in adult male GCTs.

\section{AP activity in MSGs during lactation (group L) (Fig. 10)}

During lactation, AP activity of GCTs significantly decreased and the SMG of lactating females gradually lost its „masculine“ enzymic pattern. However, between lactating day 5 and 15, the GCTs retained some AP activity. At the 10th lactating day, the AP activity of GCT was intermediate between that seen in pregnant females (or adult males) and non-pregnant adult females, whereas on the 21 st lactating day (day of weaning) the gland already displayed a „female" type of AP activity (with histochemically negative or only a few positive GCTs).

\section{Discussion}

The histochemical demonstration of alkaline phosphatase in the parenchyma of salivary glands of various mammals has been reported by a number of authors $(1,13,14,18)$. Andrews and Bulock (1) reported strong AP activity in the male granular convoluted tubules of murine SMG. Hill and Bourne (14) described a slight AP reaction in some acinar cells of MSGs of mice. Garrett and Harrison (13) noted AP activity in the myoepitelial-cell plasma membranes adjacent to the secretory acini of the MSGs of cats and also in nonmucous acini of the SLG of dogs. Leeson (18) demonstrated AP activity in the myoepithelial cells of rat salivary glands.

The present study describes the light microscopic localization and intensity of AP activity in MSGs of laboratory mice during postnatal gland differentiation, and during pregnancy and lactation. A survey of literature has noted no reports on AP distribution in developing murine salivary glands, or in the glands during pregancy and lactation as yet. Our investigation also documents that AP is a good marker for developing and mature Ac, male GCTs, as well as the arterial part of the capillary bed of MSGs.

We have shown that AP activity in MSGs was undetectable histochemically on the day of birth, appeared in the TTs and SMG IDs during the 1st postnatal week, and then gradually decreased in these structures to disappear at the end of the 3rd week. However, we showed that during the 2nd week, AP activity appeared in region of developing Ac of all three investigated glands. From the 2nd to 6th week of age, AP activity of basal parts of Ac slowly increases in the SLG and PG.

The postnatal development of AP activity in murine SMG can be divided into two phases. In the 1st phase in 23-week-old prepubescent animals, the enzymic pattern in developing male SMG is the same as in females. In the 2nd phase in 4-6-week-old pubescent animals, the enzymic pattern is sexually different, the female glands exhibit generally less activity than male ones. In fully differentiated SMG of adult young or old animals this histochemical sexual dimorphism is more pronounced than in SMG of adolescent animals. The enzyme reaction is strong in adult male Ac and GCTs, whereas the reaction is only slight in female Ac, and negative (or sporadically very weakly positive) in female GCTs. It has been known for more than five decades that the SMG of laboratory mice (Mus musculus) exhibits morphological sex dimorphism (17). Number of studies has demonstrated differences between male and female SMG in mice $(1,7,14,23)$. We have shown that sexual differences in intensity and localization of AP activity in adolescent, young and old adult mice exist too.This finding confirms an androgenic dependence of GCTs and indicates a high metabolic activity of male GCTs (which are massive producers of biologically active peptides) (2) and probably plays a different biologic role in males and females. Corresponding to our observations, Andrews and Bullock (1) described strong AP activity in the male GCTs but none in female GCTs of SMG of adult mice. On the other hand, Hill and Bourne (14) found no histochemical sexual differences of AP activity in adult murine SMG.

We have observed that the SMG of mice shows histochemical „masculinization“ during pregnancy. This SMG masculinization is characterized by numerous, large and histochemically strongly positive GCTs of pregnant fema- 
les. The maximum of this masculinization occurs between pregnancy day 15 and day 21 (birth of offspring). During lactation, AP activity of GCTs is gradually decreasing and on lactating day 21 (the day of weaning), GCTs already displays the „female“ type of AP activity. Although Desclin (11) reports that progesterone has no masculinizing effect on the morphology of murine female SMG, other authors have shown that progesterone stimulates the SMG $(26,31)$. The SMG of mice is a typical androgen target organ and contains receptors for androgens that can be characterized and quantified (33). Studies in Tfm/y mice also show that SMG of these animals is insensitive to progestagens, suggesting that progesterone acts via androgenic receptors. Progesterone could interact directly with the receptors for androgen, or after its biotransformation into steroid C 19 (26). In fact, progesterone can be converted into 5-alpha-dihydrotestosterone in some androgen target organs such as the SMG of mice, showing that the masculinization effect of progesterone takes place after conversion into androgens (20). While the concentration of progesterone in blood starts to decrease from the 17 th day of pregnancy, progestin is very high in the rat SMG till delivery (22).This hormone retention in the glandular tissue could enable the histochemical masculinization of SMG till the 21st day of pregnancy, which our study seems to support.

In the MSGs, AP appears as a good marker of the CECs. Enzyme activity of CECs develops during the first postnatal weeks. In a complex delineation of the capillary bed (with the aid of AP and AChE in the same section), AP maps out the arterial parts of capillaries, whereas AChE depicts the venous part of the capillary bed (the middle part displays activity of both enzymes).This finding documents a heterogeneity of CECs of the capillary bed in murine MSGs.

\section{Conclusion}

1) A complex topo-histochemic picture of AP activity in murine MSGs during various periods of postnatal life (in newborn, prepubescent, pubescent, young adult and old animals of both sexes), as well as during pregnancy and lactation is presented. In our study, AP appears as a good marker of developing and mature Ac, male GCTs and CECs.

2) AP activity is absent on the day of birth in the parenchyma of all MSGs and appears during the 1st postnatal week in TTs, transitional structures of gland parenchyma. During week 2, AP activity in basal region of developing Ac of all three glands is recognized. During the 4th postnatal week the first signs of AP activity in male GCTs are revealed.

3) AP activity in basal parts of Ac and male GCTs gradually increases with postnatal differentiation of the glandular parenchyma. Definitive enzymic pattern is present in the MSGs at the end of the 6th week of age. There is no difference in enzymic activity between young adult and old animal glands. The parenchyma of SMG demonstra- tes a more intense AP reaction than the parenchyma of SLG and PG.

4) Distinct sexual differences of AP activity are observed in the SMG. Histochemical sexual dimorphism is not obvious until 3 weeks of age. In adolescent animals (from the 4 th week on) a clear histochemical sex dimorphism is evident but is not yet as pronounced as in the mature SMG of adult mice. AP activity in basal parts of Ac is more intense in adult males than in females. GCTs of fully differentiated SMG of adult males are strongly positive, whereas GCTs of adult females are negative or only sporadically very weakly positive. This finding confirms an androgenic dependence of GCTs (primarily known from histological studies) and indicates a high metabolic activity of male GCTs.

5) „Masculinization“ of female SMG occurs during pregnancy (with a maximum from the 15th day of gestation till delivery) with the development of numerous, large, histochemically strongly positive GCTs. Progesterone produced during pregnancy apparently stimulates the transformation of the "female" type of GCTs into a metabolically highly AP positive „male“ type. This histochemical „masculinization“of GCTs gradually decreases after delivery, and at the end of lactation the gland again assumes the „female“ type of activity (with histochemically negative or only sporadically very weakly positive GCTs).This histochemical masculinization of the SMG during pregnancy indicates that not only androgens but also progesterone exerts masculinization of this gland.

6) AP appears as a good marker of the arterial parts of capillaries in the MSGs.

\section{References}

1. Andrews EJ, Bulock LP. A morphological and histochemical evaluation of sexual dimorphism in androgen -intensive pseudohermaphroditic mice. Anat Rec 1972; 174:361-70.

2. Barka T. Biologically active polypeptides in submandibular glands. J Histochem Cytochem 1980;28:836-59.

3. Bogart BI. The fine structural localization of alkaline and acid phosphatase activity in the rat submandibular gland. J Histochem Cytochem 1968; 16:572-81.

4. Borgers M, Firth JA, Stoward PJ. Histochemical methods for phosphatases. In: Stoward PJ, Pearse AGE, eds. Histochemistry. Theoretical and Applied. Edinburgh, London, Melbourne, New York and Tokyo: Churchill Livingstone, 1991: 591-606.

5. Borgers M, Firth JA, Stoward PJ, Verheyen A. Phosphatases. In: Stoward PJ, Pearse AGE, eds. Histochemistry. Theoretical and Applied. Edinburgh, London, Melbourne, New York and Tokyo: Churchill Livingstone, 1991: 187-218.

6. Bucci M, Murphy CHR. Alkaline phosphatase distribution in the plasma membrane of uterine epithelial cells is 
markedly altered during pregnancy in the rat. Cell Biol Int 1995;19:921-8.

7. Chai Y, Klauser D, Denny PA, Denny PC. Proliferative and structural differeneces between male and female mouse submandibular glands. Anat Rec 1993;235:303-11.

8. Chretien M. Action of testosterone on the differentiation and secretory activity of a target organ: The submaxillary gland of the mouse. Int Rev Cytol 1977; 50:333-96.

9. Denny PC, Chai Y, Pimprapaiporn W, Denny PA. Threedimensional reconstruction of adult female mouse submandibular gland secretory structures. Anat Rec 1990; 226:489-500.

10. Denny PC, Chai Y, Klauser DK, Denny PA. Parenchymal cell proliferation and mechanism for maintenance of granular duct and acinar cell population in adult male mouse submandibular gland. Anat Rec 1993; 235:47585.

11. Desclin J Jr. Action de la progestérone sur la structure des glandes sous-maxillaires chez la souris. C R Hebd Séanc Acad Sci 1967; 264:367-9.

12. Fukuda M. Histochemical studies on the rat submaxillary gland during postnatal development. Histochemie 1967; 8:342-54.

13. Garrett JR, Harrison JD. Alkaline phosphatase and adenosine triphosphatase histochemical reaction in the salivary glands of cat, dog and man, with particular reference to the myoepithelial cells. Histochemistry 1971;24:214-29.

14. Hill CR, Bourne GH. The histochemistry and cytology of the salivary gland duct cells. Acta Anat 1954;20:116-28. 15. Hoshi K, Amizuka N, Oda K, Ikehara Y, Ozawa H. Immunolocalization of tissue non-specific alkaline phosphatase in mice. Histochem Cell Biol 1997;107:183-91.

16. Johanson S, Wide M. Changes in the pattern of expression of alkaline phosphatase in the mouse uterus and placenta during gestation. Anat Embryol 1994; 190:287-96.

17. Laccassagne A. Dimorphism sexuel de la glande sous maxillaire chez la souris. C R Soc Biol 1940;133:181-226.

18. Leeson CR. Localization of alkaline phosphatase in the submaxillary gland of the rat. Nature 1956; 178:858-9.

19. Lojda Z. Heterogenita endotelu mikrocirkulace se zvláštním zřetelem $\mathrm{k}$ mikrocirkulaci CNS. In: Mitro A, Pogády J, eds. Histochémia a morfológia atruktúr nervového systému a cirkulácie. KÚNZ Bratislava, 1988:1-8.

20. Mowszowiecz I, Bieber DE, Chung KW, Bullock LP, Bardin CW. Synandrogenic and antiandrogenic effect of progestis: Comparison with non-pregestational antiandrogens. Endocrinology 1974; 95:1589-92.

21. Oliver C, Lewis PR, Stoward PJ. Histochemical methods for esterases. In: Stoward PJ, Pearse AGE, eds. Histochemistry. Theoretical and Applied. Edinburgh, London, Melbourne, New York and Tokyo: Churchill Livingstone, 1991:591-606.

22. Paulo E, Szoltys M. Steroid hormone content in the submandibular gland of normal and pregnant rats. Arch Oral Biol 1982;27:887-95.
23. Pardini LC, Taga R. Stereological study of the sexual dimorphism in mouse submandibular glands. Okajimas Folia Anat Jap 1996;73:119-24.

24. Pinero GJ, Farach CM, Devoll RE, Aubin JE, Brunn JC, Butler WT. Bone matrix proteins in osteogenesis and remodelling in the neonatal rat mandible as studied by immunolocalization of osteopontine, bone sialoprotein, alpha 2HS-glycoprotein and alkaline phosphatase. Arch Oral Biol 1995;40:145-55.

25. Pinkstaff CA. The cytology of salivary glands. Int Rev Cytol 1980;63:141-261.

26. Rossi JA, Bruschi LC. Alteration of the submandibular glands of female mice during pregnancy and lactation. A histological, histometric and histochemical study. Acta Morphol Hung 1989;37:135-45.

27. Roux F, Durieu-Trautmann $\mathrm{O}$, Chaverot $\mathrm{N}$ et al. Regulation of gamma-glutamyl transpeptidase and alkaline phosphatase activities in immortalized rat brain microvessel endothelial cells. J Cell Physiol 1994 ;159:101-13.

28. Sawada K, Noumura T. Sexually dimorphic duct system of the submandibular gland in mouse with testicular feminization mutation (Tfm/y). Acta Anat 1992;143:241-5.

29. Sims-Samson G, Gresik E, Barka T. Histochemical localization of ouabain-sensitive, $\mathrm{K}+$-dependent $\mathrm{p}$ Nitrophenylphosphatase ( $\mathrm{Na}+-\mathrm{K}+-$ ATPase) activity in the submandibular gland of the mouse: Effect of androgen, thyroid hormone, or postnatal age. Anat Rec 1984;210:53-60. 30. Srinivasan R, Chang WWL. The postnatal development of the submandibular gland of the mouse. Cell Tiss Res 1979; 198:363-71.

31. Travill A.The effect of pregnancy on the submandibular gland of mice. Anat Rec;1966;155:217- 25.

32. Waymire KG, Mahuren JD, Jaje JM, Guilarte TR, Coburn SP, Mac Gregor GR. Mice lacking tissue nonspecific alkaline phosphatase die from seizures due to defective metabolism of vitamin B-6. Nat Genet 1995;11: 45-51.

33. Wilson JD, Goldstein JL. Evidence for increased cytoplasmatic androgen binding in the submandibular gland of the mouse with testicular feminization. J Biol Chem 1972;247: 7342-9.

34. Zhang Y, Shao JS, Xie QM, Alpers DH. Immunolocalization of alkaline phosphatase and surfactant-like particle proteins in rat duodenum fat absorption . Gastroenterology 1996;110:478-88.

Submitted March 1998.

Accepted May 1998.

MUDr. Blanka Pospísilová, CSc., Department of Anatomy, Charles University, Faculty of Medicine, Šimkova 870, 50001 Hradec Králové, Czech Republic. 